\title{
Toplumdan Kazanılmış Pnömoni Tanısıyla Yoğun Bakımda Yatarak Tedavi Görmüş Hastalarda Mortaliteyi Etkileyen Faktörler
}

\section{Factors Affecting Mortality in Intensive Care Patients with the Diagnosis of Community Acquired Pneumonia}

\author{
Melek Memoğlu ${ }^{1}$ Songül Özyurt ${ }^{* 2}$, Neslihan Özçelik², Aziz Gümüş ${ }^{2}$ Ünal Şahin² \\ ${ }^{1}$ Bayburt Devlet Hastanesi, Göğüs Hastalıkları Kliniği, Bayburt, Türkiye \\ ${ }^{2}$ Recep Tayyip Erdogan Üniversitesi, Göğüs Hastalıkları Ana Bilim Dalı, Rize, Türkiye \\ e-mail: melekmemoglu53@gmail.com,drsongul@gmail.com,ozcelik.nesli@gmail.com, \\ azizgumus@gmail.com,drunsahin@yahoo.com \\ ORCID: 0000-0001-6389-3393 \\ ORCID: 0000-0002-9768-1425 \\ ORCID: 0000-0002-4672-6179 \\ ORCID: 0000-0001-5396-5402 \\ ORCID: 0000-0003-1836-6193 \\ *Sorumlu Yazar / Corresponding Author: Sorumlu Yazar: Songül Özyurt
}

Gönderim Tarihi / Received:28.05.2020

Kabul Tarihi / Accepted: 23.09.2020

DOI: $10.34087 /$ cbusbed.744260

\section{$\ddot{\mathbf{O} z}$}

Giriş ve Amaç: Çalışmamızda toplumdan kazanılmış pnömoni tanısıyla yoğun bakımda yatan hastalarda mortaliteyi etkileyen faktörlerin araştırılması amaçlanmıştır.

Gereç ve Yöntem: Çalışmaya Ocak 2014- Ocak 2017 tarihleri arasında hastanemiz Göğüs Hastalıkları polikliniği ve acil servis ünitesine başvurmuş ve hastanemiz yoğun bakım ünitelerine toplumdan kazanılmış pnömoni tanısılya kabul edilen toplam 50 vaka alındı. Olguların demografik özellikleri, ek hastalıkları, yatışının 1.,4. ve 7. gününde laboratuar bulguları, invaziv mekanik ventilasyon (IMV) uygulanma durumu, yatış süreleri kaydedildi ve mortalite ile ilişkisi incelendi.

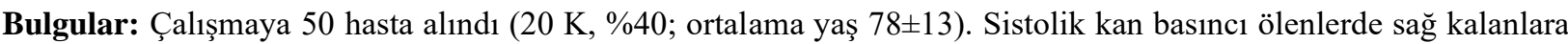
göre istatistiksel olarak anlamlı olacak şekilde daha düşük saptandı $(p=0,035)$. Ölenlerde yatışın 1 . gününde bakılan total protein anlamlı derecede düşük $(\mathrm{p}=0,022)$, 4. günde bakılan üre anlamlı ölçüde yüksek $(\mathrm{p}<0,05)$, glukoz değeri anlamlı ölçüde yüksek ( $p=0,035)$, C-reaktif protein (CRP) değeri anlamlı ölçüde yüksek $(p=0,011)$ tespit edildi. 7 . gününde bakılan albumin değeri anlamlı ölçüde düşük tespit edildi $(p=0,005)$. Ölenlerde 1 . ve 4 . gün karşılaştırıldığında platelet değerindeki düşme $(p=0,001)$, protein değerindeki düşme $(p=0,001)$, albümin değerindeki düşme $(p=0,001)$, laktikdehirogenaz $(\mathrm{LDH})$ değerindeki artış $(\mathrm{p}=0,022)$, PCO2 değerindeki artış $(\mathrm{p}=0,029)$ mortalite açısından istatistiksel olarak anlamlı saptanmıştır. Ölenlerin yaş ortalaması daha yüksek bulunmuş, bu durum istatistiksel olarak anlamlı saptanmıştır $(\mathrm{p}=0.023)$.

Sonuç: İleri yaş, sistolik kan basıncında düşüklük, PLT, total protein ve albümin düzeylerinin düşük seyretmesi, LDH yüksekliği, tedaviye rağmen CRP ve beyaz küre sayısında (WBC) beklenen düşüşün olmaması, PCO2 değerinde artış yoğun bakım ünitesinde takip edilen toplum kökenli pnömoni hastalarında mortalite belirteci olarak kullanılabilir.

Anahtar Kelimeler: Mortalite, Toplumdan kazanılmış pnömoni, Yoğun bakım ünitesi

Abstract

Objective: In our study, it was aimed to investigate the factors affecting mortality in patients hospitalized in intensive care unit with the diagnosis of community-acquired pneumonia (CAP).

Material and Methods: 50 patients with severe pneumonia who were admitted to either Pulmonary and Emergency Department and accepted to our intensive care unit with CAP between January 2014 and January 2017 were recruited. Demographic features, comorbid diseases, laboratory findings on the 1st, 4th, and 7th days of hospitalization, the status of invasive mechanical ventilation (IMV), duration of hospitalization were recorded and their relationship with mortality was examined. 
Results: Fifty patients (mean age: $78 \pm 13$ years, $40 \%$ females) were included in the study. The mean age of the fatal cases was found to be higher $(\mathrm{p}=0.023)$. Systolic blood pressure was found to be lower in deads $(\mathrm{p}=0.035)$. In dead patients, plasma total protein levels was significantly lower $(p=0.022)$. Plasma urea levels $(p<0.05)$, fasting blood glucose levels $(\mathrm{p}=0.035)$, CRP levels $(\mathrm{p}=0.011)$ were significantly higher at the fourth day of hospitalization in dead cases. Plasma albumin levels measured at the seventh day of admission was lower in dead patients $(\mathrm{p}=0.005)$. Comparison between the first and the fourth day of admission revealed that the reduction in the platelet (PLT) counts $(p=0.001)$, total protein levels $(p=0.001)$ and albumin levels $(p=0.001)$ and also the increase in the LDH levels $(p=$ $0.022)$ and in the $\mathrm{pCO}_{2}$ measurements $(\mathrm{p}=0.029)$ were found to be statistically significant in terms of mortality during follow up.

Conclusion: Advanced age, lower systolic blood pressure, lower serum total protein and albumin levels, elevated LDH levels, poor reduction in CRP and WBC despite treatment, an increase in pCO2 measurements were considered to be related with mortality in community-acquired pneumonia patients followed up in intensive care unit.

Key Words: Community-acquired pneumonia, Intensive care unit, Mortality

\section{Giriș}

Toplumdan kazanılmış pnömoniler (TKP), tüm dünyada yaygın ve ciddi bir enfeksiyon hastalığıdır. Avrupa'da yetişkin nüfusta yıllık insidans \%0,5-1,1 olarak bildirilmektedir; sepsis, şiddetli sepsis ve septik şokun en s1k nedenidir [1]. Ayaktan tedavi edilen hastalarda mortalite \%1-5 iken, hastanede tedavi edilen olgularda ortalama mortalite \%12 civarındadır. Antibiyotik ve aşılardaki gelişmelere, hastane kaynaklı ve toplum kökenli pnömoni hastalarının yönetimine yönelik kılavuzların yayınlanmasına rağmen, yoğun bakım ünitesine (YBÜ) pnömoni tanısı ile yatırılan hastalar için ise ölüm oranı yaklaşık \%15-50 arasında bildirilmektedir [1].

Yapılan çalışmalarda TKP'de hastalığın ağırlığı ve mortalite ile ilgili birçok risk faktörü bulunmuştur. Yaş, cinsiyet, ek hastalıklar, bazı laboratuvar parametreleri, biyomarkerlar, vital bulgular, pnömoni ağırlık skorları, yoğun bakım hastalık şiddeti skorlaması bu faktörler arasındadır. $\mathrm{Bu}$ çalışmadaki amacımız toplumda gelișen pnömoni tanısıyla yoğun bakımda takip edilen hastalarda mortaliteyi etkileyen faktörlerin araştırılmasıdır.

\section{Materyal ve Metod:}

Çalışmamız retrospektif olarak yapılmıştır. Çalışmaya Ocak 2014 - Ocak 2017 tarihleri arasında Recep Tayyip Erdoğan Üniversitesi Tip Fakültesi Eğitim ve Araştırma Hastanesi göğüs hastalıkları polikliniği ve acil servis ünitesine başvurmuş ve başvuru esnasında veya yatışından sonra ilk 48 saatten kısa sürede hastanemiz yoğun bakım ünitelerine TKP tanısıyla kabul edilen 50 vaka alındı. Gebeler, 18 yaş altı hastalar, aspirasyon pnömonisi ve hastanede gelişen pnömonisi olanlar, aktif akciğer kanserli hastalar, yatışı esnasında başka bir nedenle ölenler (miyokard infarktüsü, pulmoner emboli gibi) dışlandı.

Olguların demografik özellikleri, ek hastalıkları, invaziv mekanik ventilasyon (IMV) uygulanma durumu, yatış süreleri ve mortaliteleri kaydedildi. Olguların hastaneye başvuru şikâyetleri, başvuru anında yapılan fizik muayene bulgularından bilinç durumu, vücut sicaklığı, arteryel tansiyon (TA) ve nabız verilere eklendi. Başvuru esnasında (1. gün), yatışın 4. ve 7. günlerinde çalışılan arter kan gazı değerleri (AKG) kaydedildi. Olguların 1., 4. ve 7. gününde bakılan hemogram, genel biyokimya, CRP parametreleri ve yatışlarında alınan idrar, balgam, kan ve gaita kültür sonuçları kaydedildi. Başvuru sırasında çekilen toraks bilgisayarlı tomografi (BT) bulguları kaydedildi. Ayrıca yatan hastaların Glaskow koma skoru ve Akut Fizyoloji ve Kronik Sağlik Değerlendirme (Acute Physiology and Chronic Health Evaluation $=$ APACHE II) skoru hesaplanarak kaydedildi.

Çalışmamızın etik kurul onayı Recep Tayyip Erdoğan Üniversitesi Tıp Fakültesi Etik Kurulundan alınmıştır (Etik Kurul Karar No:2017/37).

\section{İstatistiksel Yöntemler}

İstatistiksel analiz için SPSS 22 istatistik programı kullanıldı. Verilerin değerlendirilmesinde sürekli değişkenler ortalama \pm standart sapma, kategorik değişkenler ise \% olarak ifade edildi. İki grubun karşılaştırılmasında T-student veya Mann-Whitney U testi kullanıldı. Değişkenler arasındaki ilişki Pearson veya spearmans korelasyon analizi ile incelendi. Kategorik değişkenlerin karşılaştırmasında Ki-Kare testi kullanıldı. $\mathrm{P}<0.05$ değeri istatistiksel olarak anlamlı kabul edildi.

\section{Bulgular}

30'u (\%60) erkek, 20'si (\%40) kadın olmak üzere toplam 50 hasta ile yapılan çalışmamızda mortalite oranı \%60 olarak bulundu. Olgularımızın yaş ortalaması $78 \pm 13$ (48-99) olup ölenlerin ortalama yaş1 $81 \pm 13$, yaşayanların ortalama yaşı $73 \pm 12 \mathrm{idi}$. Ölenlerin yaş ortalaması daha yüksek bulunmuş, bu durum istatistiksel olarak anlamlı saptanmıştır $(\mathrm{p}=0.023)$. Çalışmada cinsiyet ve mortalite arasında istatistiksel olarak anlamlı farklılı saptanmadi $(\mathrm{p}=0,386)$. Çalışmamızda hastaların en sik başvuru şikayetleri genel durum bozukluğu (\%94) ve nefes darlığı $(\% 88)$ idi (Tablo1).

Hastalarımızda saptanan en sık komorbiditeler \%46 ile HT, \%42 ile KAH, \%38 ile KKY idi (Tablo1). Komorbiditeler ile mortalite arasında anlamlı ilişki saptamadik. Çalışmamızda ölenlerde ortalama yatış süresi 7,8 $\pm 8,5$ yaşayanlarda $15,55 \pm 15,5$ olarak saptanmıştır. Ölenlerin yatış süresinin, sağ kalanlara göre istatistiksel olarak anlamlı olacak şekilde k1sa olduğu görüldü $(\mathrm{p}<0,027)$. 
Tablo 1. Hastaların başvuru şikayetleri ve ek hastalıklarının dağılımı

\begin{tabular}{|c|c|c|}
\hline Şikayeti & $\begin{array}{c}\text { Var } \\
\text { n }(\%)\end{array}$ & $\begin{array}{c}\text { Yok } \\
\text { n (\%) }\end{array}$ \\
\hline Göğüs ağrısı & $2(\% 4)$ & $48(\% 96)$ \\
\hline Oral alım bozukluğu & $7(\% 14)$ & $43(\% 86)$ \\
\hline Öksürük & $20(\% 40)$ & $30(\% 60)$ \\
\hline Balgam & $24(\% 48)$ & $26(\% 52)$ \\
\hline Nefes darlı̆̆1 & $44(\% 88)$ & $6(\% 12)$ \\
\hline Genel durum bozukluğu & $47(\% 94)$ & $3(\% 6)$ \\
\hline Senkop & $4(\% 8)$ & $46(\% 92)$ \\
\hline İştahsızlık & $5(\% 10)$ & $45(\% 90)$ \\
\hline Ek hastalıklar & & \\
\hline Diyabetes mellitus (DM) & $9(\% 18)$ & $41(\% 82)$ \\
\hline Serebrovasküler olay (SVO) & $16(\% 32)$ & $34(\% 68)$ \\
\hline $\begin{array}{l}\text { Konjestif kalp yetmezliği } \\
(\mathrm{KKY})\end{array}$ & $19(\% 38)$ & $31(\% 62)$ \\
\hline Hipertansiyon (HT) & $23(\% 46)$ & $27(\% 54)$ \\
\hline $\begin{array}{l}\text { Koroner arter hastalığ } 1 \\
\text { (KAH) }\end{array}$ & $21(\% 42)$ & $29(\% 58)$ \\
\hline $\begin{array}{l}\text { Kronik böbrek yetmezliği } \\
(\mathrm{KBY})\end{array}$ & $10(\% 20)$ & $40(\% 80)$ \\
\hline Akciğer Dışı Malignite & $11(\% 22)$ & $39(\% 78)$ \\
\hline $\begin{array}{l}\text { Kronik obstrüktif akciğer } \\
\text { hastalığ }(\mathrm{KOAH})\end{array}$ & $7(\% 14)$ & $43(\% 86)$ \\
\hline Alzheimer & $9(\% 18)$ & $41(\% 82)$ \\
\hline
\end{tabular}

Ölen hastalarda APACHI II skoru $30.37 \pm 8,7$ iken sağ kalanlarda 26,90 $\pm 5,8$ saptand 1 ve durum mortalite ile ilişkili bulunmadı $(\mathrm{p}=0,123)$.

Hastaların hastaneye yatışı sırasında kaydedilen vital bulguları ve oksijen saturasyonları ile mortalite

ilişkisine bakıldı. Sadece sistolik kan basıncı (SKB) ölenlerde sağ kalanlara göre istatistiksel olarak anlamlı olacak şekilde daha düşük saptandı $(p=0,035)$. Hastaların vital bulguları ile mortalite arasındaki ilişki Tablo-2' de gösterilmiştir.

Tüm hastalardan yatışında (1.gününde), yoğun bakım takiplerinin 4. ve 7. gününde hemogram, biyokimyasal parametreler, CRP ve AKG alınarak bu değerlerin mortalite ve sağ kalım ile ilişskileri incelendi. Yatış anında bakılan total protein düzeyi ölen hastalarda sağ kalanlara göre istatistiksel olarak anlamlı derecede düşük bulundu $(\mathrm{p}=0,022)$. Diğer biyokimya parametrelerinde ise iki grup arasında anlamlı farklılık saptanmadi. Fakat albümin değeri ölen hastalarda daha düşük saptanmış olmasına rağmen mortalite açısından istatistiksel olarak anlamlı değildi $(p=0,095)$. Üre değeri ölen hastalarda yaşayanlara göre belirgin yüksek olmasına rağmen istatistiksel olarak anlamlı saptanmadi $(p=0,074)$.

Ölen hastalarda yoğun bakım ünitesinde 4. Gün bakılan CRP, üre ve glukoz değerlerinin yüksek, Kalsiyum (Ca) değerlerinin ise düşük olması mortalite açısından istatistiksel olarak anlamlıyd $1(p<0,05)$. Yoğun bakım takiplerinde 7. günde ise kalsiyum ve albümin düşüklüğü mortalite açısından istatistiksel olarak anlamlı idi (sırasiyla $\mathrm{p}=0,030, \mathrm{p}=0,005)($ Tablo3).

Tablo 2. Hastaların vital bulguları ile mortalite arasındaki ilişki

\begin{tabular}{|l|c|c|c|}
\hline \multirow{2}{*}{ Vital Bulgular } & $\begin{array}{c}\text { Ölen Hastalar } \\
\mathbf{N = 3 0} \\
\text { (Ortalama } \pm \text { Std. Sapma) }\end{array}$ & $\begin{array}{c}\text { Sağ Kalan Hastalar } \\
\text { N=20 } \\
\text { (Ortalama } \pm \text { Std. Sapma) }\end{array}$ & $\boldsymbol{P}$ \\
\hline ATEŞ $\left({ }^{\circ} \mathbf{C}\right)$ & $36,7 \pm 0,5$ & $36,66 \pm 0,4$ &, 764 \\
\hline SKB(mmHg) & $100 \pm 26,3$ & $117,65 \pm 29,9$ &, $\mathbf{0 3 5}$ \\
\hline DKB (mmHg) & $60 \pm 17,6$ & $63,00 \pm 21,1$ &, 592 \\
\hline NABIZ (/dk) & $107 \pm 22,6$ & $98,40 \pm 22,2$ &, 183 \\
\hline SO2 \% & $89 \pm 8,3$ & $88,30 \pm 12,6$ &, 719 \\
\hline
\end{tabular}

SKB: Sistolik Kan Basıncı, DKB: Diyastolik Kan Basınc1, SO2\%: oksijen saturasyonu. 
Tablo 3. Laboratuar parametreleri ile mortalite arasındaki ilişki

\begin{tabular}{|c|c|c|c|}
\hline \multicolumn{4}{|c|}{ Yatışının 1. Günü Mortalite ile İliş̧ili Laboratuar Bulguları } \\
\hline & $\begin{array}{c}\text { Ölen Hastalar } \\
\mathbf{n}=\mathbf{3 0}\end{array}$ & $\begin{array}{c}\text { Sağ Kalan Hastalar } \\
\qquad=20\end{array}$ & \multirow[t]{2}{*}{$p$} \\
\hline & Ortalama \pm Std. Sapma & Ortalama \pm Std. Sapma & \\
\hline Protein $(\mathrm{g} / \mathrm{dL})$ & $6,46 \pm 0,8$ & $7,04 \pm 0,8$ & ,022 \\
\hline \multicolumn{4}{|c|}{ Yatışının 4.Günü Mortalite ile İlişsili Laboratuar Bulguları } \\
\hline & $\begin{array}{c}\text { Ölen Hastalar } \\
n=19\end{array}$ & $\begin{array}{c}\text { Sağ Kalan Hastalar } \\
n=20\end{array}$ & $p$ \\
\hline Üre (mg/dL) & $127,7 \pm 58,6$ & $61,0 \pm 33,0$ & ,001 \\
\hline Glukoz (mg/dl) & $188,3 \pm 151,9$ & $109,6 \pm 37,2$ & ,035 \\
\hline Kalsiyum (mg/dl) & $7,4 \pm 0,8$ & $8,0 \pm 0,4$ & ,004 \\
\hline $\operatorname{Crp}(\mathrm{mg} / \mathrm{dl})$ & $16,1 \pm 10,4$ & $8,7 \pm 4,9$ & ,011 \\
\hline Platelet (hc/uL) & $168310 \pm 97470$ & $227289 \pm 91054$ & ,062 \\
\hline Total bilirubin $4(\mathrm{mg} / \mathrm{dL})$ & $1,2 \pm 1,2$ & $0,6 \pm 0,3$ & ,058 \\
\hline \multicolumn{4}{|c|}{ Yatışının 7. Günü Mortalite ile İlişsili Laboratuar Bulguları } \\
\hline & $\begin{array}{c}\text { Ölen Hastalar } \\
n=11\end{array}$ & $\begin{array}{l}\text { Sağ Kalan Hastalar } \\
n=20\end{array}$ & $p$ \\
\hline Kalsiyum (mg/dL) & $7,47 \pm 0,57$ & $7,94 \pm 0,45$ & ,030 \\
\hline Albümin (g/dL) & $2,26 \pm 0,33$ & $2,71 \pm 0,37$ & ,005 \\
\hline
\end{tabular}

Ayrıca ölen hastalarda de 1. ve 4. gün bakılan hemogram, albümin, total protein, $\mathrm{LDH}$, , CRP ve pCO2 gibi bazı laboratuvar değerlerinin mortalite ile ilişkisi bakıldı. 4 . günde platelet (PLT), albümin ve protein değerlerindeki düşme mortalite açısından anlamlı saptanmıştır (sırasılya; $\mathrm{p}=0,001, \mathrm{p}=0,001, \mathrm{p}=0,001$ ). 4. gün bakılan $\mathrm{LDH}$ ve $\mathrm{pCO} 2$ değerlerindeki artış mortalite açısından anlamlı saptanmıştır (sırasılla; $\mathrm{p}=0,022, \mathrm{p}=0,029)$ (Tablo 4).

Tablo 4. Ölen hastalarda 1-4. gün laboratuvar değerlerinin karşılaştırması ve mortaliteyle ilişkisi

\begin{tabular}{|c|c|c|c|c|c|c|}
\hline & & $1 .($ & & $4 . G$ & & \\
\hline & Sayı & Ortalama & Std. Sapma & Ortalama & Std. Sapma & \\
\hline Platelet (hc/uL) & 19 & 244000 & 121916,1 & 168310, & 97470,8 & ,001 \\
\hline Protein $(\mathrm{g} / \mathrm{dL})$ & 19 & 6,50 & ,98 & 5,3579 & ,80091 & ,001 \\
\hline Albümin (g/dL) & 19 & 3,01 &, 70 & 2,4579 & ,54193 & ,001 \\
\hline $\begin{array}{l}\text { Laktik Dehidrogenaz } \\
\text { (U/L) }\end{array}$ & 19 & 312,07 & 123,237 & 439,53 & 226,548 & ,022 \\
\hline pCO2 (mmHg) & 19 & 35,72 & 9,638 & 42,63 & 13,200 & ,029 \\
\hline
\end{tabular}

Sağ kalanlarda 1. ve 4. gün bakılan WBC, kreatinin, CRP, total bilirubin değerleri karşılaştırıldığında 4. Günde bu parametrelerdeki düşüşler sağ kalım açısından istatistiksel olarak anlamlı saptanmıştır (sırasıyla; $\mathrm{p}=0,001, \mathrm{p}=0,008, \mathrm{p}=0,014, \mathrm{p}=0,016)($ Tablo5). 
Tablo 5. Sağ kalanlarda 1-4. gün bazı laboratuvar değerlerinin karşılaştırması ve sağkalımla ilişkisi

\begin{tabular}{|c|c|c|c|c|c|c|}
\hline & & $1 . C$ & & 4.C & & \\
\hline & Say1 & Ortalama & Std. Sapma & Ortalama & Std. Sapma & $P$ \\
\hline WBC $10^{3} / \mathrm{UL}$ & 19 & 14528,9 & 5200,30 & 9490,53 & 3630,53 & ,001 \\
\hline Kreatinin (mg/dL) & 19 & 1,5495 & ,75587 & 1,0447 & ,87532 & ,008 \\
\hline CRP (mg/dL) & 19 & 16,0956 & 10,4963 & 8,7144 & 4,8582 & ,014 \\
\hline T.Biluribin (mg/dL) & 19 & ,9384 & ,47761 & ,6479 & 25862 & ,016 \\
\hline
\end{tabular}

WBC: White Blood Cell, CRP: C-Reaktif Protein

Hastaların yatışlarında alınan trakeal aspirasyon kültürü (TAK), idrar kültürü, kan kültürü ve gaita kültürü ile mortalite arasındaki ilişkiye bakıldı. Sağ kalanlar ile ölenler arasında çeşitli kültürlerde üreme olup olmaması yönüyle bakıldığında kültürlerin hiçbirinde anlamlı bir fark tespit edilemedi. Yatan hastalardan alınan trakeal aspirat kültürlerinin \%34'ünde üreme saptandı (Tablo-6). Hastaların kan, idrar ve balgam kültürlerinde üreyen mikroorganizmalar ile mortalite arasında ilişki saptanmamıştır.

\section{Tartışma}

Toplum kökenli pnömoni tanısı yoğun bakımda tedavi gören hastalarda yaptığımız bu çalışmada mortalite oranı \%60 idi. Ölen hastalarda yaş ortalaması sağ kalanlara göre daha yüksekti. Sistolik kan basıncı ölenlerde sağ kalanlara göre daha düşüktü. Ölen hastalarda yatışın 1 . gününde bakılan total protein anlamlı derecede düşük, 4 . günde bakılan üre anlamlı ölçüde yüksek, glukoz değeri anlamlı ölçüde yüksek, CRP değeri anlamlı ölçüde yüksek tespit edildi. Ölen hastaların albümin değeri 7. günde anlamlı ölçüde düşük tespit edildi. Ölen grupta 1. ve 4. gün karşılaștırıldığında platelet değerindeki düșme, protein değerindeki düşme, albümin değerindeki düşme, LDH değerindeki artış, PCO2 değerindeki artış mortalite açısından istatistiksel olarak anlamlı bulunmuştur.

Toplum kökenli pnömonilerin yaşlı hastalarda ( $\geq 65$ yaş), özellikle de çok yaşlılarda ( $>84$ yaş) bağ 1 şıklık sisteminin zayıflamasına bağlı olarak mortalitesinin yüksek olduğu gösterilmiştir [1,2]. 1,191 TKP hastasını içeren retrospektif bir çalışmada mortalite oranı 65-84 yaş grubunda $\% 11,9$ ve 84 yaş üzeri grupta ise $\% 20,7$ saptanmıştır [2]. Literatürle uyumlu olarak çalışmamızda ölen hastaların yaş ortalaması $81 \pm 13$ olarak bulunmuş, ileri yaş ve mortalite arasındaki ilişki istatistiksel olarak anlamlı saptanmıştır.

TKP'nin erkeklerde daha sık görüldüğü birçok çalışmada gösterilmiş ve erkek cinsiyetin daha kötü prognoz ile ilişkili olduğunu saptanmıştır [1,3]. Kaplan ve arkadaşları yaptıkları çalışmada TKP'de hastane yatışının, yoğun bakım ve yaşam desteği ihtiyacının ve ölümün erkeklerde daha fazla olduğunu göstermişlerdir [3]. Angela ve arkadaşlarının yaptıkları çalışmada kadınlarda hücresel immünitenin erkeklere göre daha gelişmiş olduğu gösterilmiş, travma ve sepsiste kadın
Tablo 6. TAK'da üreyen mikroorganizmaların dağılımı

\begin{tabular}{|c|c|c|}
\hline \multicolumn{3}{|c|}{$\begin{array}{l}\text { Trakeal aspirasyon kültüründe üreyen } \\
\text { mikroorganizmaların dağılımı }\end{array}$} \\
\hline & $\mathrm{n}$ & $\%$ \\
\hline Streptokok & 3 & 6,0 \\
\hline Streptokok+acinetobakter & 1 & 2,0 \\
\hline Stafilokok & 1 & 2,0 \\
\hline Acinetobakter & 3 & 6,0 \\
\hline Acinetobakter+candida & 2 & 4,0 \\
\hline Candida & 2 & 4,0 \\
\hline E.coli & 2 & 4,0 \\
\hline Psodomonas & 3 & 6,0 \\
\hline Toplam & 17 & 34,0 \\
\hline Bilinmiyor & 33 & 66,0 \\
\hline Toplam & 50 & 100,0 \\
\hline
\end{tabular}

seks steroidlerinin immün sistemi koruduğu bildirilmiştir [4]. Çalışmamızda cinsiyet ve mortalite arasındaki ilişkiye bakıldığında 20 kadın hastadan 13'ünün (\%65), 30 erkek hastadan 17 'sinin (\%56) öldüğü kaydedildi. Literatürden farklı olarak çalışmamızda kadınlarda ölüm oranı daha yüksek bulunmuş ancak bu durum istatistiksel olarak anlamlı değildir.

Ülkemizde YBÜ'de tedavi gerektirecek ölçüde ciddi TKP'de mortalite riski \%40 olarak tanımlanmıştır [5]. YBÜ gerektiren ciddi pnömoni hastalarının \%2550 'sinde tanıdan sonraki ilk 30 günde ölüm meydana gelmiş ve ölüm nedeni de genellikle komorbiditelere bağlanmıştır [5]. Bu çalışmada en sık saptanan komorbid hastalıklar arasında ilk sırada kronik obstrüktif akciğer hastalığ1 (KOAH) izlenmekte olup onu takiben hipertansiyon, kalp yetmezliği, diyabet, serebrovasküler hastalık ve malignite gelmektedir. Bircan A ve ark, 
pnömonide komorbidite oranını \%34 olarak tespit etmişlerdir [6]. Köksal ve ark, ayaktan takip edilen ve yatan 218 hastada \%42,7 olguda KOAH, \%29,8 hipertansiyon, \%9,6 kalp yetmezliği ve \%8,7 oranında diyabet bildirmişlerdir [7]. Çalışmamızda saptanan en sık komorbiditeler sirasiyla HT, KAH ve KKY idi. Dai ve ark. yaptıkları çalışmada TKP'ye eşlik eden KOAH'lı hastalar incelenmiş ve yoğun bakım ihtiyacını artırdığ1 saptamıştır [8]. Yang ve ark yaptığı çalışmada sigara içme, solunum yetmezliği ve kalp yetmezliği öyküsü olan hastalarda mortalite yüksek saptanmıştır [9]. Çalışmamızda ise komorbidite varlığı yoğun bakım ihtiyacı ve mortalite açısından istatistiksel olarak anlamlı saptanmadi.

Rei F. ve ark yaptığı çalışmada düşün kan basıncı mortalite açısından anlamlı saptanmış [10], Muhammed İrfan ve ark. yaptığı çalışmada solunum hızı, konfüzyon mortalite açısından anlamlı saptanmış, ancak kan basıncı mortalite açısından risk faktörü olarak saptanmamıştır [11]. Çalışmamızda vital bulgulardan yalnızca SKB ölenlerde sağ kalanlara göre istatistiksel olarak anlamlı olacak şekilde daha düşük saptandi $(p=0,035)$.

Yoğun bakım ünitelerinde hastalığın ağırlığını, tedaviye yanıtını, beklenen ölüm oranını ve yoğun bakım performasını saptayabilmek için APACHI II gibi skorlama sistemleri kullanılmaktadır [12]. Richards G. ve ark. yaptığı çalışamada TKP ve ağır sepsisi olan ve APACHE II $\geq 25$ olan hastalarda 28 günlük mortalite $\% 43,5$ olarak saptanmıştır [13]. Dai ve ark. yaptığg çalışmada pnömoni ve KOAH birlikteliğinde APACHE II skoru daha yüksek saptanmış ve bu durum mortalite açısından anlamlı bulunmuştur [8]. Aydoğdu ve ark. yaptığı çalışmada YBÜ'lerde sıklıkla kullanılan APACHE II skorunun artmışdeğerleri mortalite ile ilişskili bulunmuştur (APACHE II > 20 odds ratio: 3, \%95 CI: $1.2-7, p=0.024)$ [14]. Çalışmamızda APACHE II skoru ölenlerde ortalama 30 olarak hesaplandı. Ölenlerde daha yüksek saptanmış olmasına rağmen mortalite açısından istatistiksel olarak anlamlı saptanmadı. $\mathrm{Bu}$ durum çalışmaızdaki hasta sayısının az olması ile ilişkilendirilebilir.

C-Reaktif Protein, İnterleukin-6'ya yanıt olarak karaciğer tarafından sentezlenen bir akut faz reaktanıdır [15]. Günlük CRP ölçümü sepsisin takibinde WBC'den daha hassastır [16]. Sistemik inflamatuvar yanıt sendromunda (SIRS), YBÜ hastalarında enfeksiyon tanısı ve takibi için CRP kullanışlıdır. Reny ve ark yaptığı bir çalışmada 1. ve 4. günler arasında CRP'nin $\geq 50 \mathrm{mg} /$ $\mathrm{L}$ azalması iyileşmenin en iyi göstergesi olarak bulunmuştur [17]. Chalmers ve ark. yaptığı bir çalışmada hastaların giriş CRP $<100 \mathrm{mg} / \mathrm{L}$ olmasının 30 günlük mortaliteyi, mekanik ventilasyon ihtiyacını ve / veya inotropik desteğini ve komplike pnömoni riskini azalttığ 1 , CRP'nin 4. günde $\% 50$ veya daha fazla düşmemesi durumunda bu risklerin, mortalite oranının arttığını göstermişler ve CRP, toplum kökenli pnömonide bağımsız bir belirteç olarak kabul etmişlerdir [15]. Çalışmamızda ölenlerin CRP değeri 4. günde anlamlı ölçüde yüksek tespit edildi. Yaşayanlarda ise 1. ve 4. gün bakılan CRP değerleri karşılaştırıldığında, CRP değerindeki düşme sağ kalım açısından istatistiksel olarak anlamlı bulundu. Bu nedenle CRP takibi mortalite tahmininde kullanılabilecek önemli bir biyobelirteçtir. Albümin, akut inflamasyon durumunda bir negatif akut faz reaktanıdır. Hipoalbüminemi, malnütrisyona bağlı yaşlı hastalarda daha sık görülür ve hastalığın kötü seyrine sebep olur [18]. Ayrica, pnömonisi olan hastalarda akut inflamasyona bağlı olarak da hipoalbüminemi görülebilir [19]. Lee ve ark. yaptıkları bir çalışmada TKP'si olan ve hastanede yatan hastalarda albümin değerlerinin bağımsız olarak 28 günlük mortalite ile ilişkili olduğunu bulmuşlar $(\mathrm{p}<0.05)$, bu belirteç pnömoni ağırlık indexi (PSI) ile kombine edildiğinde prognostik performansı artırdığını görmüşlerdir [20]. So Yeon Lee ve arkadaşları retrospektif bir çalışma ile 797 TKP tanılı hastada 30 günlük mortaliteyi etkileyen bağımsız faktörlerini araştırmışlar ve düşük serum albümin seviyesi $(<3 \mathrm{~g} / \mathrm{dl})$ ve dispnenin mortaliteyi etkilediğini saptamışlardır [21]. Biz semptomlar ile mortalite arasında ilişki saptamadık fakat yatış anında bakılan total protein ölenlerde yaşayanlara göre anlamlı derecede düşük bulundu, albümin ise 7. günde yapılan ölçümlerde ölenlerde anlamlı ölçüde düşük tespit edildi. Yine çalışmamızda ölenlerde 1. ve 4. günde bakılan protein ve albümin değerleri karşılaştırıldığında protein ve albümin değerlerindeki düşme mortalite açısından istatistiksel olarak anlamlı saptanmıştır. Bu bulgular total protein ve albüminin tedavi sirasındaki seyrinin mortalite tahmininde kullanılabileceğini göstermektedir.

Daha önce toplumdan kazanılmış pnömoni ile ilgili yapılan çalışmalarda ölenlerde kan üre azotunun yüksek, serum albümin seviyesinin düşük olduğu gösterilmiştir. Dehidratasyon varlığında, böbreklerin üre reabsorbsiyonu artar, bu nedenle kan üre nitrojen seviyesi sıklıkla pnömoni hastalarında yüksek görülür. Ugajin M. ve arkadaşları 1075 TKP hastasını içeren bir çalışmada kan üre azotu (BUN) / serum albümin oranının (B/A) mortalite ile ilişkisini incelemişler ve $\mathrm{B} / \mathrm{A}$ oranının pnömoni şiddeti ve mortalitesiyle ilişkili bağımsız bir faktör olduğunu saptamışlardır $(p=0,037) \quad$ [22]. Çalışmamızda ilk gün bakılan üre ve kreatinin değerleri ölenlerde daha yüksek saptanmış olmasına rağmen istatistiksel olarak anlamlı değldi. Ancak, 4. günde üre değerlerine bakıldığında ölenlerin üre değeri istatistiksel olarak anlamlı ölçüde yüksek tespit edildi. Yaşayanlarda 1. ve 4. gün bakılan kreatin değerleri karşılaştırıldı̆̆ında ise kreatinin değerindeki düşüş mortaliteyi olumlu etkilemesi açısından istatistiksel olarak anlamlı saptandı. $\mathrm{Bu}$ bulgular hastaların oral alımlarının düzelmesi, dehidratasyonun gerilemesi ve renal perfüzyonun düzelmesine bağlı olabilir, bu bilgiler 1şığında kan üre ve kreatinin değerlerinin seyrinin mortalite tahmininde kullanılabileceği düşünülmüştür.

Trombositler, antimikrobiyal savunmada önemli rol oynayan inflamatuar hücrelerdir. Trombositopeni veya trombositoz çeşitli TKP patojenleri ile ilişkili ve ciddi TKP'si olan erişkinlerde prognoz açısından belirleyici olabilmektedir. Trombositozun eşlik edebileceği TKP patojenleri arasında $\mathrm{Q}$ ateşi ve Mycoplasma pneumoniae 
bulunur [23]. Trombositopeni ile ilişkili olabilen TKP patojenleri arasinda sitomegalovirüs, insan parainfluenza virüsü tip 3, H1N1, H5N1, ağır ARDS, Hantavirus pulmoner sendromu ve benzeri yer alır. Trombositopeni nadir olarak bakteriyel TKP'lerle de iliş̧ilendirilmiştir [23]. Mirsaeidi ve ark. yaptıkları retrospektif bir çalışmada; hastaneye yatmış 500 TKP tanılı hastada anormal trombosit (trombositopeni veya trombositoz) ve lökosit sayısının 30 günlük mortaliteyle ilişkili olup olmadığını araştırmış ve trombosit sayısını 30 günlük mortalite ile güçlü bir şekilde ilişkili olduğu saptanmıştır, ancak lökosit sayısı ile mortalite arasında böyle bir ilişki saptamamışlardır. $\mathrm{Bu}$ çalışmanın sonucunda TKP'li hastalarda anormal trombosit sayıs1, anormal lökosit sayısından daha iyi bir sonuç göstergesi olarak kabul edilmiştir [24]. Çalışmamızda ölenlerde 1. ve 4. gün bakılan trombosit değerleri karşılaştırıldığında; trombosit değerindeki düşme mortalite açısından anlamlı saptanmıştır.

Ayrıca çalışmamızda tedavi başladıktan sonraki takiplerde WBC değerindeki düşme olumlu bir gösterge olup sağkalım açısından istatistiksel olarak anlamlı saptanmıştır.

Hastaların hastanede yatış süresini etkileyen faktörler üzerine çok sayıda çalışma yapılmıştır. Menendez ve arkadaşlarının 295 TKP hastasında yaptıkları çalışmada, yatış süresinin uzamasına etki eden faktörlerin pnömoni, komorbid durumlar ve komplikasyonların gelişmesi olduğu bildirilmiştir [25]. Çalışmamızda ölenlerde ortalama yatış süresinin daha kısa olduğu bulunmuştur ve bu durumun TKP tanısı ile yoğun bakıma yatırılan hastaların hastalıklarının ağır seyretmesi ve kısa sürede ölmelerine bağlı olduğu düşünülmüştür.

Daha önce yapılan çalışmalarda yüksek serum LDH değerlerinin mortaliteyi öngörmede faydalı olduğu bildirilmiştir $[26,27]$. Çalışmamızda ölenlerde 1. ve 4 . gün bakılan LDH değerleri karşılaştırıldığında LDH değerindeki artış mortalite açısından anlamlıydı.

Bilirubin, antioksidan ve antiinflamatuar özelliklere sahiptir. Ong ve ark. yaptığı bir kohort çalışmasında total bilirubin düzeylerinin, tüm yaşlı popülasyonda toplam mortalite ile ilişkisini araştırdılar vetotal bilirubin düzeyleri 0,1 ile $0,4 \mathrm{mg} / \mathrm{dl}$ arasında olanlarda mortalite en fazla saptanmıştır, ancak yüksek bilirubin düzeylerinin mortaliteyle daha fazla ilişkide olabileceği düşünülmüştür [28]. Çalışmamızda yaşayanlarda 1. ve 4. gün bakılan total bilirubin değerleri karşılaştırıldığında total bilirubin değerindeki düşme prognoza olumlu katkı sağlamıştır.

Acil servislere başvuran hastalarda elektrolit bozuklukları sık görülmesine rağmen, acil servis hastalarında hiperkalsemi ve hipokalsemi prevalansı ve sonuçları hakkında çok az çalışma yapılmıştır. Zivin ve ark. tarafından yapılan bir çalışmada hipokalseminin yoğun bakım ünitesinde çok sık görüldüğü ve hastalığın şiddeti ve mortalite ile ilişkili olduğu bulunmuş ancak belirli bir hastalık ile korelasyon bulunamamıştır [29]. Sauter ve ark. 8270 hastayı içeren bir çalışma yapmışlar, klasik risk faktörlerinin yanı sıra acil servislerde hiperkalsemi ve hipokalseminin mortalite için bağımsız yeni risk faktörleri olduğunu göstermişlerdir [30]. Çalışmamızda da sağ kalanlarda kalsiyum değeri ölenlere göre anlamlı ölçüde yüksek tespit edilmiştir.

\section{Sonuç}

Sonuç olarak ileri yaş, sistolik kan basıncında düşüklük, trombosit, total protein ve albümin düzeylerinin düşük seyretmesi, LDH ve bilirubin yüksekliği, tedaviye rağmen CRP ve WBC'de beklenen düşüşün olmaması, yoğun bakım ünitesinde takip edilen toplum kökenli pnömoni hastalarında mortalite belirteci olarak kullanılabilir.

Retrospektif bir çalışma olması ve hasta sayısının az olması çalışmamızın kısıtlılıklarıdır.

\section{Kaynaklar}

1.Welte, T, Risk factors and severity scores in hospitalized patients with community-acquired pneumonia: prediction of severity and mortality, European Journal of Clinical Microbial Infectious Diseases, 2012, 31, 33-47.

2.Cabre, M, Serra-Prat, M, Bolibar, I, Pallares, R, Prognostic factors of community-acquired pneumonia in very old patients, Medical Clinics (Barc), 2006, 127(6), 201-205.

3.Kaplan, V, Angus, DC, Griffin, MF, Clermont, G, Scott Watson, R, Linde Zwirble, WT, Hospitalized community-acquired pneumonia in the elderly: age and sex related patterns of care and outcome in the United States, American Journal of Respiratory Critical Care Medicine, 2002, 165(6), 766-772.

4.Angela, MK, Frantz, MC, Chaudry III, Gender and sex hormones influence the response to travma and sepsis: potential therapeutic approaches, Clinics (Sao Paulo), 2006, 61(5), 479-488.

5.Ceylan, E, (2014), Toplumda Gelişen Pnömoni: Risk Faktörleri ve Tanısal Yaklaşım. Erişim tarihi: 15.05.2018.(http://www.klimik.org.tr/wpcontent/uploads/2014/10/Toplumda-Gelișen-Pnömoni-RiskFaktörleri-ve-Tanisal-Yaklaşım-Emel-CEYLAN.pdf)

6.Bircan, A, Sütçü, R, Gökırmak, M, Hiçyılmaz, H, Akkaya, A, Öztürk, Ö, Total Antioxidant Capacity and C-Reactive Protein Levelsin Patients with Community-Acquired Pneumonia, Turkish Journal of Medical Sciences, 2008, 38, 537-44.

7. Köksal, I, Ozlü, T, Bayraktar, O, Yılmaz, G, Bülbül, Y, Oztuna, F, Caylan, R, Aydın, K, Sucu, N; TUCAP Study Group, Etiological agents of community-acquired pneumonia in adult patients in Turkey; a multicentric, cross-sectional study, Tuberkuloz Toraks Dergisi, 2010, 58(2), 119-27.

8.Dai, RX, Kong, QH, Mao, B, Xu, W, Tao, RJ, Wang, XR, Kong QY, $\mathrm{Xu}, \mathrm{JF}$, The mortality risk factor of communityacquiredpneumonia patients with chronic obstructive pulmonary disease: a retrospective cohort study, BMC Pulmonary Medicine, 2018, 22;18(1):12.

9.Yang, Y, Chang, SS, Liu, JJ, Et al, Efficacy and significance of various scores for pneumonia severity in the manegement of patients with community-acquired pneumonia in China DIAO Ran, Chinase Medical Journal, 2012, 125, 639-645

10. Fujiki, R, Kawayama, T, Ueyama, T, Ichiki, M, Aizawa, H, The risk factors for mortality of community-acquired pneumonia in Japan, Journal of Infection and Chemotherapy: Official Journal of the Japan Society of Chemotherapy, 2007, 13 (3), 157-65.

11. Irfan, M, Hussain, S.F, Mapara, K, Memon, S, Mogri, M, Bana, M, Malik, A, Khan, S, Khan, N.A, Community Acquired Pneumonia: Risk factors associated with mortality in a tertiary care hospitalized patients, Journal of Pakistan Medical Association, 2009,59(7).

12. Godinjak, A, Iglica, A, Rama, A, et al, Predictive value of SAPS II and APACHE II scoring systems for patient outcome in a medical intensive care unit, Acta Medical Academy, 2016, 45(2), 97-103.

13. Richards, G, Levy, H, Laterre, P.F, Feldman, C, Woodward, B, Bates, B.M, Qualy RL.CURB-65, PSI, and APACHE II to assess mortality risk in patients with severe sepsis and community acquired pneumonia in PROWESS, Journal of Intensive Care Medicine, 2011 , 26(1), 34-40. 
14. Aydoğdu, M, Özy1lmaz, E, Aksoy, H, Gürsel, G, Eki, N, Mekanik ventilasyon ihtiyacı olan toplum kökenli pnömoni hastalarının mortalite tahmininde pnömoni ve yoğun bakım skorlarının değeri, Tüberküloz ve Toraks Dergisi, 2010, 58(1), 25-34

15. Chalmers, J.D, Singanayagam, A, Hill, A.T, C-reactive protein is an independent predictor of severity in community-acquired pneumonia, American Journal of Medicine, 2008, 121(3), 219-25.

16. Póvoa, P, Almeida, E, Moreira, P, Fernandes, A, Mealha, R, Aragão, A, Sabino, H, C-reactive protein as an indicator of sepsis, Intensive Care Medicine, 1998, 24(10),1052-6.

17. Reny, J.L, Vuagnat, A, Ract, C, Benoit, M.O, Safar, M, Fagon, J.Y Diagnosis and follow-up of infections in intensive care patients: value of C-reactive proteincompared with other clinical and biological variables, Critial Care Medicine, 2002, 30(3), 529-35.

18. Harimurti K et.al, C-reactive Protein Levels and Decrease of Albumin Levels in Hospitalized Elderly Patients with Community-Acquired Pneumonia, Acta Medica Indonesia (Indonesian Journal of Internal Medicine), 2007, 39(1), 13-8

19. Hedlund, J.U, Hansson, L.O, Ortqvist, A.B, Hypoalbuminemia in hospitalized patients with community-acquired pneumonia, Archieves Internal Medicine, 1995, 10;155(13), 1438-42.

20. Lee, J.H, Kim, J, Kim, K, Jo, Y.H, Rhee, J, Kim, T.Y, Na, S.H, Hwang, S.S, Albumin and C-reactive protein have prognostic significance in patients with community-acquired pneumonia, Journal of Critical Care, 2011, 26(3), 287-94.

21. Lee, S.Y, Cha, S, Sea, H et al, Multimarker prognostication for hospitalized patients with community-acquired pneumonia, Internal Medicine, 2016, 55, 887-893.

22. Ugajin, M, Yamahi, K, Wamra N, et al, Blood urea nitrogen to serum albumin ratio independently predicts mortality and severity of community-acquired pneumonia, Internal Journal of General Medicine, 2012, 5, 583.

23. Cunha, B.A, Hage, J.E, Community-acquired pneumonia: diagnostic vs prognostic significance of the platelet count, Chest, 2011, 139(5), $1255-1256$

24. Mirsaeidi, M, Peyrani, P, Aliberti, S, Filardo, G, Bordon, J, Blasi, F, Ramirez, J.A, Thrombocytopenia and thrombocytosis at time of hospitalization predict mortality in patients with community-acquired pneumonia, Chest, 2010, 137(2), 416-20.

25. Menendez, R, Ferrando, D, Valles, J.M, Martinez, E, Perpina, M, Initial risk class and length of hospital stay in community-acquired pneumonia, European Respiratory Journal, 2001, 18, 151-6.

26. Lipman, M.L, Goldstein, E, Serum lactic dehydrogenase predicts mortality in patients with AIDS and Pneumocystis pneumonia, Western Journal of Medicine, 1988, 149(4), 486-7.

27. Kolsuz, M, Uçgun, İ, Metintaş, M, Erginel, S, Harmancı, E, Alataş, F, Hastaneye yatarak veya yoğun bakımda tedavi görmesi gereken toplum kökenli pnömonilerde mortaliteyi etkileyen faktörler, Tüberküloz ve Toraks Dergisi, 2002, 50(2), 229-238.

28. Ong, K.L, Allison, M.A, Cheung, B.M, Wu, B.J, Barter, P.J, Rye, K.A, The relationship between total bilirubin levels and total mortality in older adults: the United States National Health and Nutrition Examination Survey (NHANES) 1999-2004, PLoS One, 2014, 11, 9(4), e94479.

29. Zivin, J.R, Gooley, T, Zager, R.A, Ryan, M.J, Hypocalcemia: a pervasive metabolic abnormality in the critically ill, American Journal of Kidney Diseases, 2001, 37(4), 689-98.

30. Sauter, T.C, Lindner, G, Ahmad, S.S, Leichtle, A.B, Fiedler, G.M, Exadaktylos, A.K, Haider, D.G, Calcium Disorders in the Emergency Department: Independent Risk Factors for Mortality, PLoS One, 2015, 14;10(7), e0132788.

http://edergi.cbu.edu.tr/ojs/index.php/cbusbed isimli yazarın CBU-SBED başlıklı eseri bu Creative Commons Alınt1-Gayriticari4.0 Uluslararası Lisansı ile lisanslanmıştır. 